\title{
Effects of passive immunization of goats against inhibin on follicular development, hormone profile and ovulation rate
}

\author{
M. S. Medan ${ }^{1}$, G. Watanabe ${ }^{2}$, K. Sasaki ${ }^{3}$, Y. Nagura ${ }^{4}$, H. Sakaime ${ }^{4}$, \\ M. Fujita ${ }^{4}$, S. Sharawy ${ }^{1}$ and K. Taya ${ }^{2 *}$ \\ ${ }^{1}$ Department of Theriogenology, Faculty of Veterinary Medicine, Suez Canal University, Ismailia, Egypt; \\ ${ }^{2}$ Laboratory of Veterinary Physiology, Tokyo University of Agriculture and Technology, 3-5-8 Saiwai-cho, \\ Fuchu, Tokyo 183-8509, Japan; ${ }^{3}$ Hitachi Ltd, Central Research Laboratory, Tokyo 185-8601, Japan; \\ and ${ }^{4}$ National Livestock Breeding Center, Nagano Station, Nagano, Japan
}

\begin{abstract}
This study was conducted to investigate the effect of immunoneutralization against endogenous inhibin on FSH secretion and ovulation rate, with the aim of developing a new superovulation method using inhibin antiserum in goats. Two groups of goats received an i.v. injection of either $10 \mathrm{ml}$ normal goat serum (control; $n=6$ ) or $10 \mathrm{ml}$ inhibin antiserum developed against $\left[\mathrm{Tyr}^{30}\right]$-inhibin $\alpha$ (1-30) $(n=6) 48 \mathrm{~h}$ before treatment with prostaglandin $F_{2 \alpha}\left(P G_{2 \alpha}\right)$. Blood samples were collected at $6 \mathrm{~h}$ intervals and ovaries were examined each day using a B-mode ultrasound scanner equipped with a $7.5 \mathrm{MHz}$ transducer during the experimental period. Immunization against inhibin resulted in a four- to fivefold increase $(P<0.01)$ in plasma concentrations of FSH. After luteolysis, plasma concentrations of oestradiol increased markedly to reach a preovulatory peak, which was about two times higher
\end{abstract}

$(P<0.01)$ than that of the controls. The treatment was accompanied by a significant increase in the total number of follicles of $\geqslant 3 \mathrm{~mm}$ in diameter at $24(8.2 \pm 0.4$ in inhibin antiserum group versus $4.8 \pm 0.3$ in control group) and $96 \mathrm{~h}$ later $(13.5 \pm 1.0$ in inhibin antiserum group versus $5.3 \pm 0.6$ in control group). The ovulation rate was significantly $(P<0.01)$ higher in goats treated with inhibin antiserum $(4.2 \pm 0.5 ; n=6)$ than in control goats $(1.8 \pm 0.3 ; n=6)$. These results indicate that inhibin is an important factor in the regulation of FSH secretion in goats and demonstrate that passive immunization against inhibin at $48 \mathrm{~h}$ before treatment with $\mathrm{PGF}_{2 \alpha}$ induces the development of more follicles and increases ovulation rate. Thus, inhibin antiserum treatment may be an alternative to the use of exogenous gonadotrophins for induction of superovulation in goats.

\section{Introduction}

Inhibin is a heterodimeric glycoprotein hormone that selectively inhibits the secretion of FSH by the pituitary gland (Burger, 1988). A negative relationship between plasma concentrations of FSH and inhibin occur in several mammalian species (Taya, 1993; Taya and Watanabe, 1999). The finding that immunoneutralization of endogenous inhibin results in a significant increase in peripheral FSH indicates that inhibin is an important factor in the inhibitory regulation of FSH secretion in domestic as well as laboratory animals (Mann et al., 1989; Rivier and Vale, 1989; Wrathall et al., 1990; Glencross et al., 1994; Campbell and Scaramuzzi, 1995; Campbell et al., 1995; Kaneko et al., 1995a, 1997; Kishi et al., 1996; Nambo et al., 1998; Shi et al., 2000). However, ultrasound images of the ovary correlate with hormone profiles and demonstrated that an increase

*Correspondence

Email: taya@cc.tuat.ac.jp in plasma $\mathrm{FSH}$ precedes the emergence of each follicular wave (Adams et al., 1992; Sunderland et al., 1994; Kaneko et al., 1995b; Evans et al., 1997) and a decrease in $\mathrm{FSH}$ is coincident with functional selection of follicles (Sunderland et al., 1994; Kulick et al., 1999), indicating that the fluctuation in peripheral FSH concentration is a trigger for growth, selection and atresia of follicles. Multiple ovulations have been induced successfully by passive immunization against endogenous inhibin in species such as rats (Rivier and Vale, 1989), sheep (Wheaton et al., 1992, 1996), hamsters (Kishi et al., 1996), cows (Akagi et al., 1997; Takedomi et al., 1997), horses (Nambo et al., 1998), guinea-pigs (Shi et al., 2000) and mice (Wang et al., 2001). Thus, these initial results indicate that immunization of animals against endogenous inhibin to induce superovulation through increased endogenous FSH secretion is an alternative method to the current exogenous gonadotrophin protocols.

In most studies, a combination of equine chorionic gonadotrophin (eCG) and hCG has been the most 
common method to induce superovulation in goats. However, a disadvantage of these protocols is the long half-life of eCG which interferes with normal fertilization and embryo development (Mclntosh et al., 1975; Armstrong et al., 1983; Ertzeid et al., 1993) and repeated eCG treatments induce anti-eCG antibodies that clearly have negative effects on reproduction of goats (Roy et al., 1999). Thus it is necessary to establish an alternative simple method for induction of superovulation in goats to overcome these problems. The aim of this experiment was to determine the effect of passive immunization against inhibin at $48 \mathrm{~h}$ before luteolysis on FSH secretion and ovulation rate in goats.

\section{Materials and Methods}

\section{Experimental animals}

Twelve goats (Capra hircus) housed under natural daylight and fed a maintenance diet of $700 \mathrm{~g}$ of hay cubes per animal per day were used in this study. Clean water and mineralized salt licks were available ad libitum. Oestrous cycles were synchronized with two injections of $125 \mu \mathrm{g}$ of a synthetic analogue of prostaglandin $\mathrm{F}_{2 \alpha}\left(\mathrm{PGF}_{2 \alpha}\right)$ (Estrumate, Schering Plough Animal Health, NJ) administered 11 days apart. Oestrous behaviour was examined at $6 \mathrm{~h}$ intervals with an aproned mature buck throughout the experimental period. On day 10 of the oestrous cycle, animals were allocated to one of two groups: (i) control, treated with i.v. injection of $10 \mathrm{ml}$ normal goat serum $(n=6)$ and (ii) inhibinimmunized, treated with i.v. injection of $10 \mathrm{ml}$ inhibin antiserum $(n=6)$. The time of the injection of serum was defined as $0 \mathrm{~h}$. At $48 \mathrm{~h}$, all animals were injected with $125 \mu \mathrm{g} \mathrm{PGF}_{2 \alpha}$ to induce oestrus and ovulation. Blood samples were collected, at $6 \mathrm{~h}$ intervals from $24 \mathrm{~h}$ before treatment until $120 \mathrm{~h}$ after treatment and at $2 \mathrm{~h}$ intervals from 48 to $72 \mathrm{~h}$ after $\mathrm{PGF}_{2 \alpha}$ injection, into heparinized Vacutainer tubes (Terumo Venoject II, Tokyo). An additional blood sample for progesterone determination was collected on day 7 after ovulation. Blood samples were centrifuged at $1200 \mathrm{~g}$ for $15 \mathrm{~min}$ at $4^{\circ} \mathrm{C}$ and plasma was separated and stored at $-20^{\circ} \mathrm{C}$ until assayed for hormones. The experimental protocol was approved in accordance with the Guide for the Care and Use of Laboratory Animals prepared by Tokyo University of Agriculture and Technology.

\section{Ultrasonography and determination of ovarian response}

The follicle populations of the animals were monitored each day starting $24 \mathrm{~h}$ before treatment until the end of the experiment and at $12 \mathrm{~h}$ intervals at the time of ovulation using a B-mode scanner (ECHOPAL ultrasound scanner, Hitachi Medical Corporation, Tokyo) equipped with a $7.5 \mathrm{MHz}$ transducer. A slightly arched plastic rod $(30 \mathrm{~cm}$ in length and $20 \mathrm{~mm}$ in diameter) was fastened to the transducer to manipulate the probe externally into the rectum. All follicles $\geqslant 3 \mathrm{~mm}$ in diameter were measured in two planes and the mean was calculated for each follicle. The occurrence of ovulation was assessed by the disappearance of large antral follicles that were present at the previous transrectal ultrasonography examination, and confirmed by detection of corpora lutea as described by Rajamahendran et al. (1989). The ovulation rate was determined by matching the number of large antral follicles that were no longer apparent with the number of corpora lutea detected by ultrasonography (Pierson and Ginther, 1988). Follicles were divided into three arbitrary groups according to their mean diameter (small: $<3.5 \mathrm{~mm}$; medium: 3.5-5.0 $\mathrm{mm}$; and large: $>5 \mathrm{~mm}$ ).

\section{Antisera}

The antiserum against inhibin used in the present study was raised in ovariectomized goats to a synthetic peptide of 1-30 amino acid sequence of the $\mathrm{N}$-terminal of the $\alpha$ chain of pig inhibin conjugated to rabbit serum albumin as described by Araki et al. (2000).

\section{Determination of inhibin binding activity}

Changes in inhibin binding activity in plasma of the inhibin-immunized goats were determined by measuring the binding of ${ }^{125}$ I-labelled inhibin (5000 c.p.m.) as reported by Kaneko et al. (1993). Plasma samples obtained at various timepoints after injection of the inhibin antiserum were diluted 1:10 with PBS containing $5 \%$ BSA. PBS $(100 \mu \mathrm{l})$ was added to each aliquot $(100 \mu \mathrm{l})$ of diluted plasma and incubated for $24 \mathrm{~h}$ at $37^{\circ} \mathrm{C}$ with ${ }^{125}$-labelled bovine inhibin of $32 \mathrm{kDa}$. Bound tracer was then separated by adding $100 \mu$ I PBS containing $1 \%$ bovine gamma globulin and $500 \mu$ l PBS containing 25\% polyethylene glycol (molecular weight 6000) for $3 \mathrm{~min}$, followed by centrifugation at $1200 \mathrm{~g}$ for $30 \mathrm{~min}$ at $4^{\circ} \mathrm{C}$. The radioactivity in the precipitate was counted. The binding activity of inhibin was expressed as a percentage of the total counts added. The intra-assay coefficient of variation was $3.9 \%$.

\section{Hormone analysis}

Plasma concentrations of FSH were measured by a radioimmunoassay system, as described by Araki et al. (2000) using anti-ovine FSH, NIDDK-FSH-I-1 for radioiodination, and NIDDK-oFSH-RP-1 as a reference standard. Plasma concentrations of $\mathrm{LH}$ were measured by radioimmunoassay as described by Mori and Kano (1984) using anti-ovine LH (YM No. 18), NIDDK-oLHI-3 for radio-iodination and NIDDK-oLH-RP-24 as a reference standard. The intra- and interassay coefficients of variation were 9.8 and $12.6 \%$ for $\mathrm{FSH}$ and 5.9 and $6.5 \%$ for $\mathrm{LH}$, respectively. Plasma concentrations 


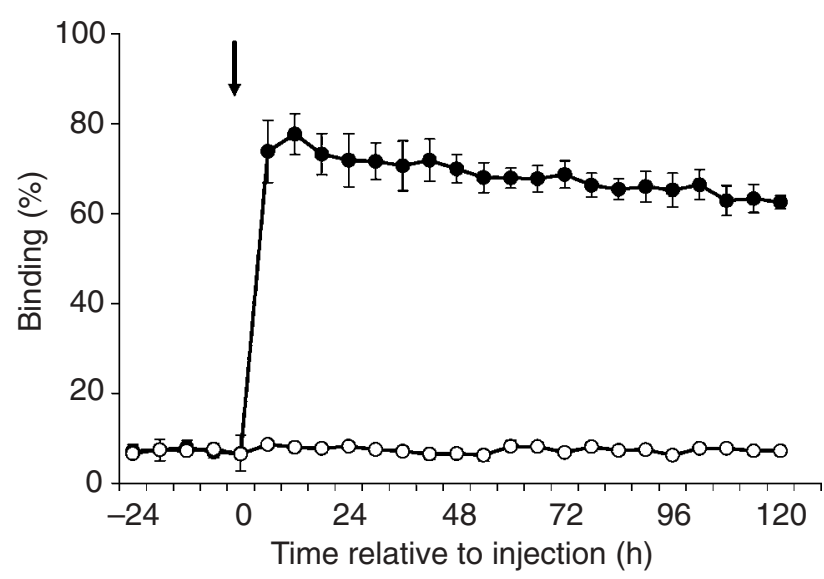

Fig. 1. Binding capacity of plasma inhibin at a dilution of $1: 10$ in goats that received an i.v. bolus injection of $10 \mathrm{ml}$ normal goat serum $(\bigcirc ; n=6)$ or $10 \mathrm{ml}$ inhibin antiserum $(0 ; n=6)$ at $0 \mathrm{~h}$ (arrow). Values are means \pm SEM.

of oestradiol and progesterone were determined by a double-antibody radioimmunoassay system using ${ }^{125} \mathrm{I}$ labelled radioligands as described by Taya et al. (1985). Antisera against oestradiol (GDN 244) and progesterone (GDN 337) were kindly provided by G. D. Niswender (Animal Production and Biotechnology, Colorado State University, Fort Collins, CO). The intra- and interassay coefficients of variation were 5.7 and $7.4 \%$ for oestradiol and 8.2 and $9.2 \%$ for progesterone, respectively.

\section{Statistical analysis}

Mean values ( \pm SEM) were calculated and analysed using two-way ANOVA. Duncan's multiple-range test was used for detection of significant differences using the SAS computer package (SAS, 1987). Wilks' Lambda correlation was made between progesterone concentrations and number of corpora lutea.

\section{Results}

\section{Binding capacity of plasma hormones}

After immunization, there was an increase $(P<0.01)$ in the ability of plasma to bind inhibin in all immunized animals. At $6 \mathrm{~h}$ after animals were immunized against inhibin, the binding capacity of inhibin in plasma at a final dilution of $1: 10$ was $77.7 \pm 6.9 \%$ compared with $8.0 \pm 0.7$ in the control group (Fig. 1). The binding capacity showed a steady decline $(P<0.01)$ over the course of the experiment in the immunized group.

\section{Plasma concentrations of FSH and $\mathrm{LH}$}

After the injection of normal goat serum, plasma concentrations of FSH did not significantly change during the period before the FSH surge. In contrast, treatment
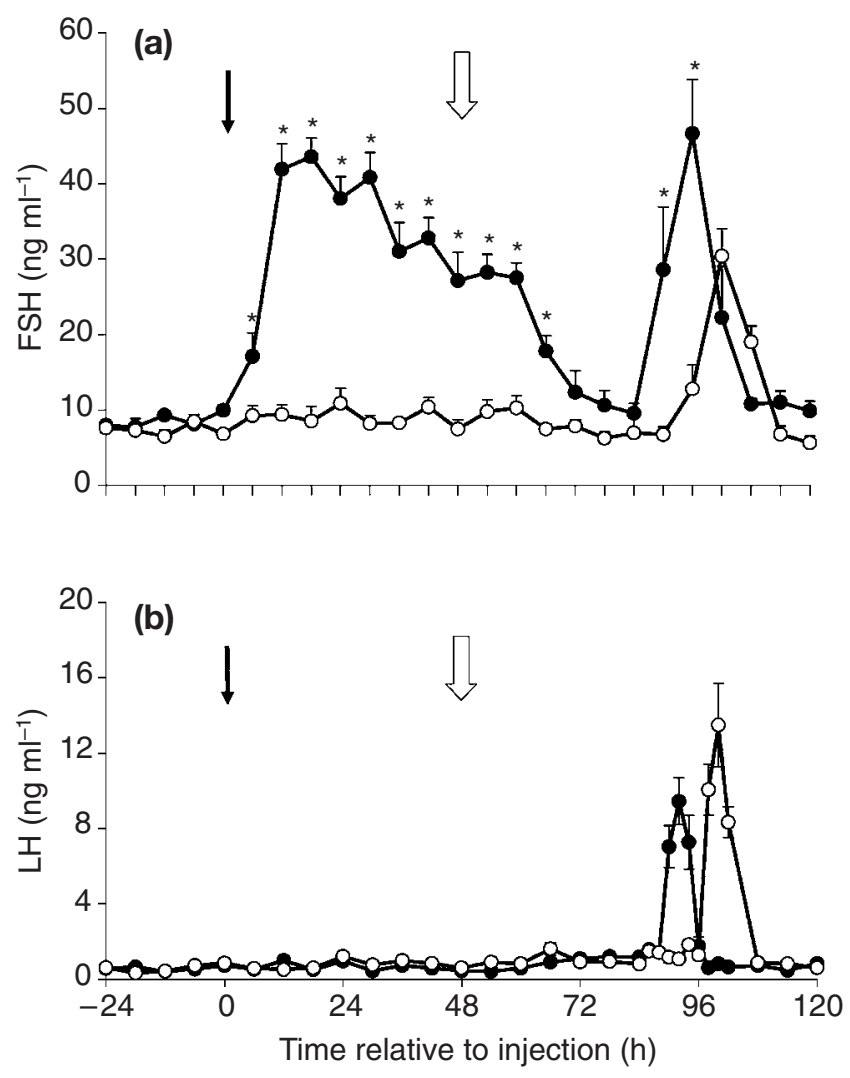

Fig. 2. Plasma concentrations of (a) FSH and (b) $\mathrm{LH}$ in goats that received an i.v. bolus injection of $10 \mathrm{ml}$ normal goat serum $(O ; n=6)$ or $10 \mathrm{ml}$ inhibin antiserum $(\mathbf{0} ; n=6)$ at $0 \mathrm{~h}$ (solid arrow) and an i.m. injection of $\mathrm{PGF}_{2 \alpha}$ at $48 \mathrm{~h}$ later (open arrow). Values are means \pm SEM. ${ }^{*} P<0.05$ compared with the control values.

with the inhibin antiserum resulted in a marked increase $(P<0.01)$ in plasma concentrations of FSH compared with control values. In the immunized group, there was a four- to fivefold increase $(P<0.01)$ in plasma FSH concentrations within $12 \mathrm{~h}$ of treatment (Fig. 2).

Thereafter, mean plasma FSH concentrations remained relatively stable for about $24 \mathrm{~h}$ and then declined $(P<0.01)$. The preovulatory FSH peak in goats immunized against inhibin occurred about $6 \mathrm{~h}$ before that of the control group and the peak value of the FSH increase in the goats immunized against inhibin was significantly higher than in the control group. There was no significant difference in the basal plasma LH concentrations between immunized $\left(0.79 \pm 0.1 \mathrm{ng} \mathrm{ml}^{-1}\right)$ and control $\left(0.86 \pm 0.1 \mathrm{ng} \mathrm{ml}^{-1}\right)$ goats. However, the LH surge tended to be lower in the immunized group compared with the control group $\left(9.4 \pm 1.2 \mathrm{ng} \mathrm{m}^{-1}(n=6)\right.$ and $13.5 \pm 2.2 \mathrm{ng} \mathrm{ml}^{-1}(n=6)$, respectively; Fig. 2$)$.

\section{Plasma concentrations of oestradiol and progesterone}

In control animals, plasma concentrations of oestradiol increased significantly $(P<0.05)$ after treatment 

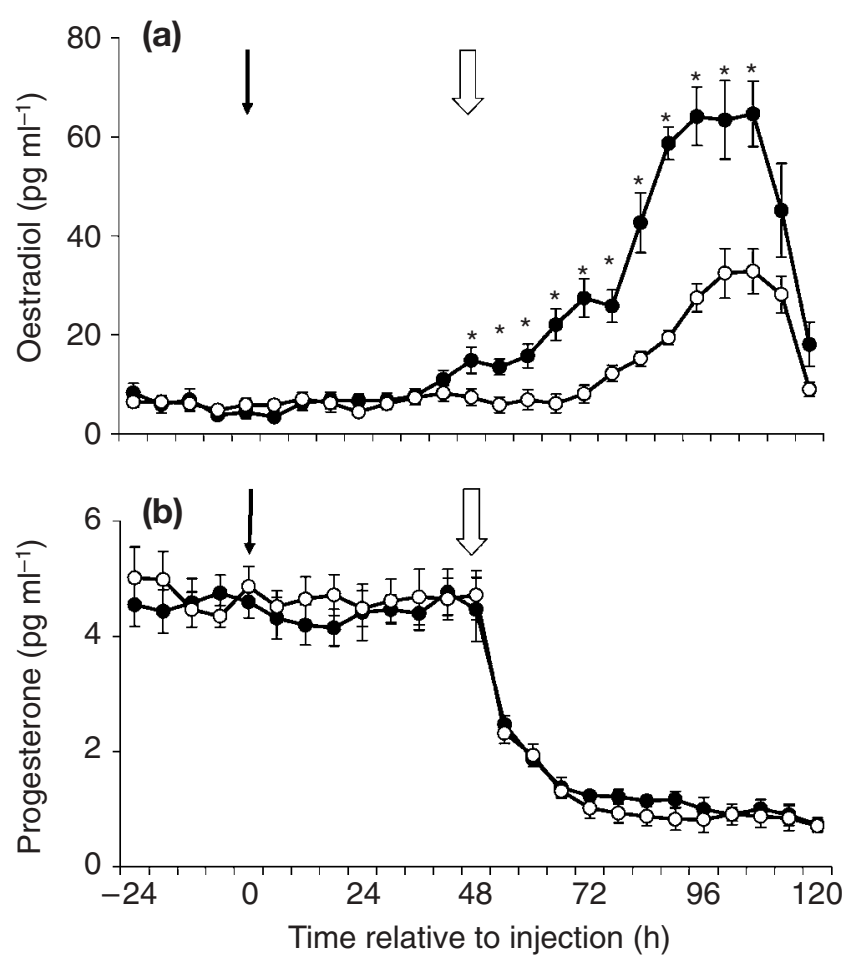

Fig. 3. Plasma concentrations of (a) oestradiol and (b) progesterone in goats that received an i.v. bolus injection of $10 \mathrm{ml}$ normal goat serum $(\bigcirc ; n=6)$ or $10 \mathrm{ml}$ inhibin antiserum $(-n=6)$ at $0 \mathrm{~h}$ (solid arrow) and an i.m. injection of $\mathrm{PGF}_{2 \alpha} 48 \mathrm{~h}$ later (open arrow). Values are means \pm SEM. ${ }^{*} P<0.05$ compared with the control values.

with $\mathrm{PGF}_{2 \alpha}$ and reached a peak $\left(32.4 \pm 5.0 \mathrm{pg} \mathrm{m}^{-1}\right)$ at about the day of oestrus. Treatment with inhibin antiserum induced a marked increase in plasma oestradiol concomitant with the growth of a large number of follicles and reached a peak $\left(64.1 \pm 5.9 \mathrm{pg} \mathrm{ml}^{-1}\right)$ at about the day of oestrus (Fig. 3).

Passive immunization against inhibin had no effect on plasma progesterone concentrations and treatment with $\mathrm{PGF}_{2 \alpha}$ at $48 \mathrm{~h}$ after administration of inhibin antiserum or normal goat serum resulted in a rapid decrease $(P<0.01)$ in progesterone concentrations in both the immunized and control groups (Fig. 3). However, during the subsequent luteal phase ( 7 days after ovulation), plasma concentrations of progesterone were significantly higher $(P<0.05)$ in immunized goats compared with control goats (Table 1). There was a significant and positive $(r=0.9 ; P<0.01)$ correlation between plasma concentrations of progesterone and the number of corpora lutea.

\section{Oestrus and ovarian response}

All goats showed signs of oestrus and ovulated. The interval from administration of $\mathrm{PGF}_{2 \alpha}$ to the onset of oestrus tended to be shorter in passively immunized goats compared with control goats (Table 1). After immunization, there was a significant $(P<0.01)$ increase in the total number of follicles ( $\geqslant 3 \mathrm{~mm}$ in diameter) in animals immunized against inhibin compared with the control group. In the group immunized with inhibin antiserum, the total number of follicles increased from a mean of $5.0 \pm 0.3$ before immunization to a mean maximum of $13.5 \pm 0.8$. The number of small $(<3.5 \mathrm{~mm})$, medium $(3.5-5.0 \mathrm{~mm})$ and large $(>5 \mathrm{~mm})$ follicles at each scan in the two groups is shown (Fig. 4). In the control group, the mean number of small, medium or large follicles did not vary significantly over the time of the experiment. In goats immunized against inhibin, small follicles increased within $24 \mathrm{~h}$ and thereafter, the number of medium and large follicles increased. Goats treated with inhibin antiserum had significantly more preovulatory follicles within the limited ovarian space compared with the control group (Fig. 5). In addition, treatment with inhibin antiserum resulted in significantly more $(P<0.01)$ ovulations than in the control group (Table 1).

\section{Discussion}

The present study clearly demonstrates that immunoneutralization of endogenous inhibin in cyclic goats results in an increase in plasma concentrations of FSH that, in turn, leads to the stimulation of ovarian follicle development and increased ovulation rate. After treatment with inhibin antiserum, plasma FSH increased and reached the highest concentration within $12 \mathrm{~h}$, but thereafter decreased to control values within $48 \mathrm{~h}$. The preovulatory FSH concentration in the immunized group reached a peak shortly before the control group. This earlier peak in FSH may be attributed to an earlier peak in oestradiol in immunized goats which, in turn, induced $\mathrm{GnRH}$ release from the hypothalamus and release of $\mathrm{LH}$ and $\mathrm{FSH}$. The decrease in FSH secretion could be attributed to FSH-stimulated oestradiol and inhibin secretion (Wheaton et al., 1992; Mann et al., 1993). The magnitude and quantitative nature of $\mathrm{FSH}$ secretory profiles induced by passive immunization support an endocrine role for inhibin in regulating FSH secretion in goats. Thus, inhibin, through regulation of FSH secretion by negative feedback, appears to be an important factor in regulation of follicular development. An FSH-mediated mechanism effect of inhibin immunization on ovulation rate is in agreement with that reported by O'Shea et al. (1994). In goats, a reciprocal relationship between circulating $\mathrm{FSH}$ and immunoreactive inhibin concentrations has been reported during the oestrous cycle (Medan et al., 2001), indicating that inhibin secreted from the ovary plays an important role as a regulator of FSH secretion. The increase in FSH concentration observed after immunization resulted in a marked stimulation of follicle growth within $24 \mathrm{~h}$. In goats immunized against inhibin, 
Table 1. Effect of passive immunization against inhibin on oestrus, ovarian response and plasma progesterone (day 7 after ovulation) in goats

\begin{tabular}{lcc}
\hline & Control group & Immunized group \\
\hline Number of treated goats & 6 & 6 \\
Number of goats detected in oestrus $^{\mathrm{a}}$ & 6 & 6 \\
Number of goats ovulating $^{\mathrm{b}}$ & 6 & 6 \\
Interval to oestrus $^{\mathrm{c}}(\mathrm{h})$ & $62.0 \pm 4.6$ & $50.0 \pm 3.4$ \\
Ovulation rate $^{\mathrm{d}}$ & $1.8 \pm 0.3$ & $4.2 \pm 0.5^{* *}$ \\
Mean maximum number of follicles $\geqslant 3$ mm in diameter $_{\text {Plasma progesterone }\left(\mathrm{ng} \mathrm{ml}^{-1} \text { ) on day } 7 \text { after ovulation }\right.}$ & $5.3 \pm 0.8$ & $13.5 \pm 0.8^{* *}$ \\
\hline
\end{tabular}

${ }^{a}$ Detected by mature bucks at $6 \mathrm{~h}$ intervals within 3 days after $\mathrm{PGF}_{2 \alpha}$ treatment.

${ }^{b}$ Detected by ultrasonography (large collapsed follicles and formation of corpora lutea at that site).

'The time (h) from $\mathrm{PGF}_{2 \alpha}$ treatment to onset of oestrus.

${ }^{\mathrm{d}}$ The number of collapsed follicles or corpora lutea per goat ovulating.

${ }^{*} P<0.05,{ }^{* *} P<0.01$ significantly different compared with the control value in the same row.
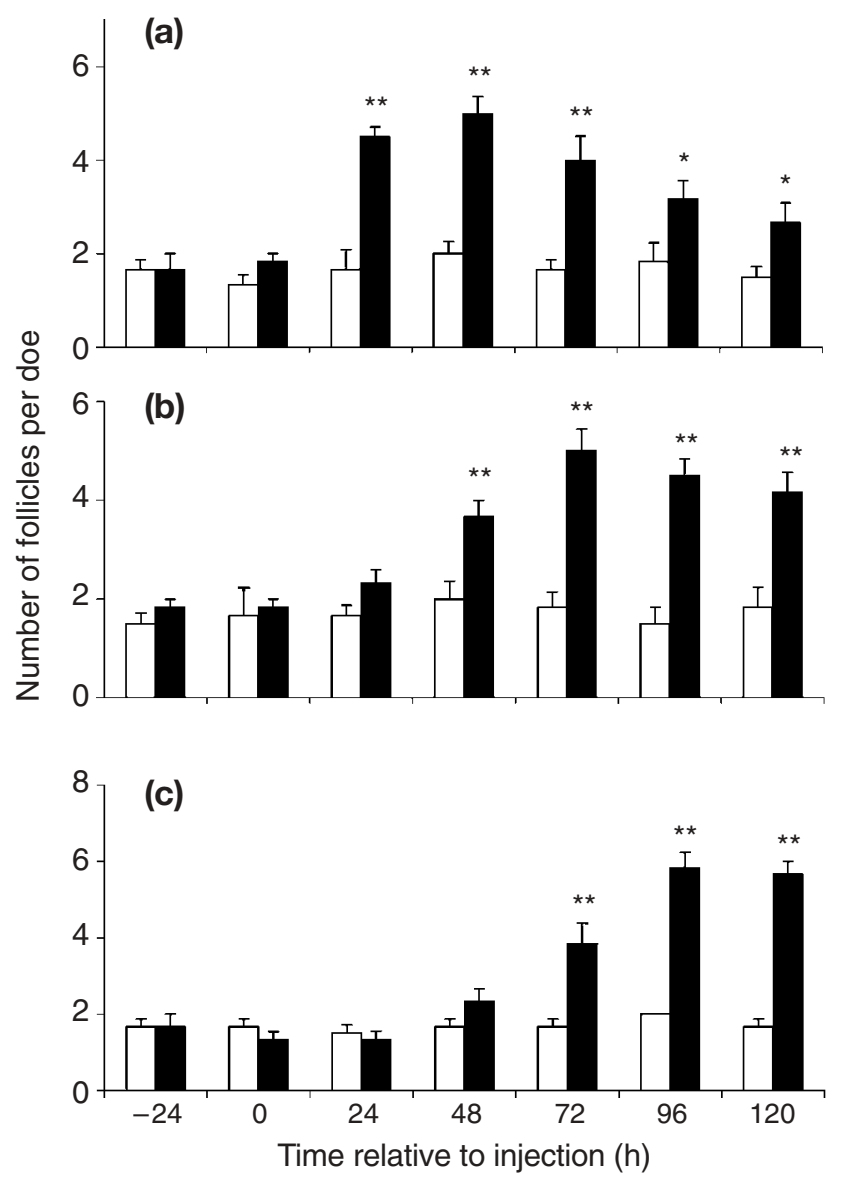

Fig. 4. Number of (a) small ( $<3.5 \mathrm{~mm}$ in diameter), (b) medium (3.5-5 $\mathrm{mm}$ in diameter) and (c) large (> $5 \mathrm{~mm}$ in diameter) follicles in goats that received an i.v. bolus injection of $10 \mathrm{ml}$ normal goat serum $(\square ; n=6)$ or $10 \mathrm{ml}$ inhibin antiserum $(\mathbf{\square} ; n=6)$ on day 10 of the oestrous cycle $(0 \mathrm{~h})$ and an i.m. injection of $\mathrm{PGF}_{2 \alpha}$ at $48 \mathrm{~h}$ later. ${ }^{*} P<0.05 ;{ }^{* *} P<0.01$ compared with control values.

there was an increase in the number of small follicles at $24 \mathrm{~h}$ after treatment with inhibin antiserum. This finding indicates tha the increase in FSH stimulated the
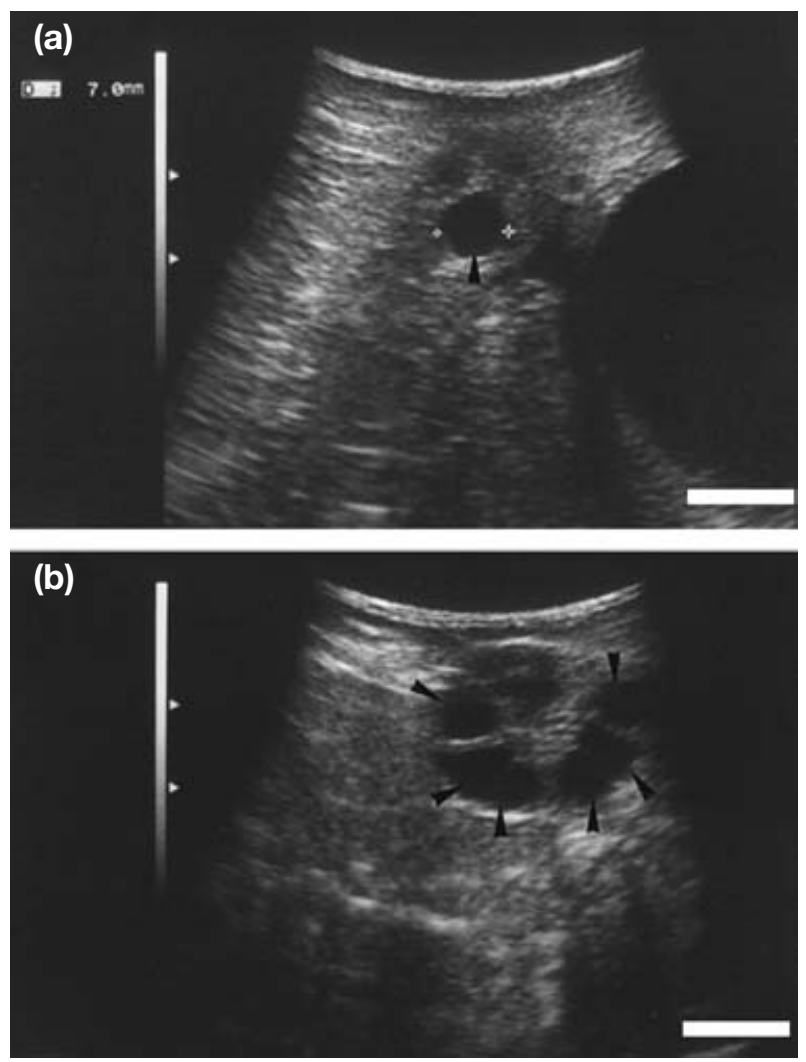

Fig. 5. Representative ultrasonography images of the goat ovary 4 days after treatment with (a) control serum or (b) inhibin antiserum. Note that many follicles are located within the limited ovarian space in the goat that had been passively immunized with inhibin antiserum (arrowheads). Scale bars represent $10 \mathrm{~mm}$.

development of a new cohort of small follicles. Similar results were reported in ewes (Mann et al., 1993). The observation that the increase in plasma FSH preceded the emergence of new follicles leads to the conclusion that hypersecretion of FSH stimulates multiple growth of follicles. Presumably, this action, timed to coincide with $\mathrm{PGF}_{2 \alpha}$ treatment in the present study, enlarges the pool 
of follicles that can be recruited, which gives rise to the greater ovulation rate in inhibin antiserum treated goats. From day 3 after injection of inhibin antiserum, the number of large follicles started to increase in association with declining plasma FSH. The results indicate that selection of large follicles occurred in the recruited follicles as a consequence of the decline in $\mathrm{FSH}$ secretion. With regards to $\mathrm{LH}$ concentrations, there was no marked change in basal $\mathrm{LH}$ concentrations between immunized and control goats. However, immunized goats displayed a lower $\mathrm{LH}$ surge than control goats. This difference might be explained by the increased oestradiol secreted by the large number of developing follicles in immunized goats. Kishi et al. (1996) reported that the preovulatory surge of plasma LH observed on the afternoon of pro-oestrus in cyclic golden hamsters was suppressed in groups treated with inhibin antiserum. In relation to these findings of a lower $\mathrm{LH}$ surge in inhibin immunized animals, Wrathall et al. (1990) reported that $\mathrm{LH}$ release induced by a $\mathrm{GnRH}$ challenge was lower in ewes actively immunized against inhibin. The marked increase in oestradiol observed in goats treated with inhibin antiserum, indicates that immunization against inhibin enhances follicular development and, in turn, secretion of oestradiol from the ovarian follicles. Similar results were recorded in cattle (Kaneko et al., 1995a; Takedomi et al., 1997). The higher progesterone concentration on day 7 after ovulation reflects a greater mass of luteal tissue (increased number of corpora lutea) as detected by ultrasonography.

It is well known that repeated use of eCG to induce superovulation in goats results in diverse effects because of the formation of anti-eCG antibodies (Roy et al., 1999). Moreover, a higher incidence of premature regression of corpora lutea in eCG-stimulated goats versus FSHsuperovulated goats was recorded (Armstrong et al., 1983; Rosnina et al., 1992; Riesenberg et al., 2001). Therefore, passive immunization against inhibin which selectively increases FSH secretion may be a suitable and simple alternative to eCG for inducing superovulation in goats. However, this protocol requires further investigation using a large number of animals and study of the repeatability and long-term effects of its use.

In conclusion, the present study demonstrated that inhibin is an important factor in the regulation of $\mathrm{FSH}$ secretion in goats and that passive immunization against inhibin $48 \mathrm{~h}$ before $\mathrm{PGF}_{2 \alpha}$ treatment induced a marked increase in $\mathrm{FSH}$, oestradiol, ovarian follicle population and ovulation rate. Therefore, the neutralization of inhibin bioactivity may be a potential method for inducing follicular development and increased ovulation rate in goats.

The authors are grateful to A. F. Parlow and the National Institute of Diabetes and Digestive and Kidney Diseases, Beltsville, MD for providing radioimmunoassay materials for ovine $\mathrm{FSH}$ and $\mathrm{LH}$; G. D. Niswender, Animal Reproduction and Biotechnology Labor- atory, Colorado State University, Fort Collins, CO for providing antisera to oestradiol-17 $\alpha$ (GDN 244) and progesterone (GDN 337). This work was supported in part by the Ito Foundation, the Japan Livestock Technology Association and a Grant-in-Aid for COE Research (E-1) from the Ministry of Education, Science, Sports and Culture, Japan.

\section{References}

Adams GP, Matteri RL, Kastelic JP, Ko JCH and Ginther OJ (1992) Association between surges of follicle-stimulating hormone and the emergence of follicular waves in heifers Journal of Reproduction and Fertility 4 177-188

Akagi S, Kaneko H, Nakanishi Y, Takedomi T, Watanabe G and Taya K (1997) Ovarian response and FSH profile in cows following injection of various doses of inhibin antiserum Journal of Veterinary Medical Science 59 1129-1135

Araki K, Arai K, Watanabe G and Taya K (2000) Involvement of inhibin in the regulation of follicle-stimulating hormone secretion in the young adult male shiba goat Journal of Andrology 21 558-565

Armstrong DT, Pfitzner AP, Warnes GM and Seamark RF (1983) Superovulation treatments and embryo transfer in Angora goats Journal of Reproduction and Fertility 67 403-410

Burger HG (1988) Inhibin: definition and nomenclature, including related substances Journal of Endocrinology 117 159-160

Campbell BK and Scaramuzzi RJ (1995) Effect of acute immunoneutralization of inhibin in ewes during the late luteal phase of the oestrous cycle on ovarian hormone secretion and follicular development during the subsequent follicular phase Journal of Reproduction and Fertility $\mathbf{1 0 4}$ 337-345

Campbell BK, Gordon BM, Tsonis CG and Scaramuzzi RJ (1995) The effect of acute immunoneutralization of inhibin in ewes during the early luteal phase of oestrous cycle on ovarian hormone secretion and follicular development Journal of Endocrinology 145 479-490

Ertzeid G, Storeng R and Lyberg T (1993) Treatment with gonadotropins impaired implantation and fetal development in mice Journal of Assisted Reproduction and Genetics 10 286-291

Evans ACO, Komar CM, Wandji SA and Fortune JE (1997) Changes in androgen secretion and luteinizing hormone pulse amplitude are associated with the recruitment and growth of ovarian follicles during the luteal phase of the bovine oestrous cycle Biology of Reproduction 57 394-401

Glencross RG, Bleach ECL, Wood SC and Knight PG (1994) Active immunization of heifers against inhibin: effects on plasma concentrations of gonadotrophins, steroids and ovarian follicular dynamics during prostaglandin-synchronized cycles Journal of Reproduction Fertility $\mathbf{1 0 0}$ 599-605

Kaneko H, Nakanishi Y, Taya K, Kishi H, Watanabe G, Sasamoto S and Hasegawa $\mathbf{Y}$ (1993) Evidence that inhibin is an important factor in the regulation of $\mathrm{FSH}$ secretion during the mid-luteal phase in cows Journal of Endocrinology 136 35-41

Kaneko H, Nakanishi Y, Akagi S, Taya K, Watanabe G, Sasamoto S and Hasegawa Y (1995a) Immunoneutralization of inhibin and estradiol during the follicular phase of the oestrus cycle in cows Biology of Reproduction 53 931-939

Kaneko H, Kishi H, Watanabe G, Taya K, Sasamoto S and Hasegawa Y (1995b) Changes in plasma concentrations of immunoreactive inhibin, oestradiol and FSH associated with follicular waves during the oestrus cycle of the cow Journal of Reproduction and Development 41 311-320

Kaneko H, Taya K, Watanabe G, Noguchi J, Kikuchi K, Shimada A and Hasegawa $\mathbf{Y}$ (1997) Inhibin is involved in the suppression of FSH secretion in the growth phase of the dominant follicle during the early luteal phase in cows Domestic Animal Endocrinology 14 263-271

Kishi H, Okada T, Otsuka M, Watanabe G, Taya K and Sasamoto S (1996) Induction of superovulation by immunoneutralization of endogenous inhibin through the increase in the secretion of follicle stimulating hormone in the cyclic golden hamster Journal of Endocrinology $\mathbf{1 5 1}$ 65-75 
Kulick LJ, Wiltbank MC and Ginther OJ (1999) Follicular and hormonal dynamics during the first follicular wave in heifers Theriogenology $\mathbf{5 2}$ 913-921

McIntosh JE, Moore RM and Allen WR (1975) Pregnant mare serum gonadotrophin: rate of clearance from circulation of sheep Journal of Reproduction and Fertility 44 95-100

Mann GE, Campbell BK, McNeilly AS and Baird DT (1989) Passively immunizing ewes against inhibin during the luteal phase of the oestrous cycle raises the plasma concentration of FSH Journal of Endocrinology 123 383-391

Mann GE, Campbell BK, McNeilly AS and Baird DT (1993) Follicular development and ovarian hormone secretion following passive immunization of ewes against inhibin or oestradiol Journal of Endocrinology 136 225233

Medan MS, Taya K, Watanabe G, Shalaby A, Sharawy S and Sasaki K (2001) Ovarian dynamics, secretion of gonadotropins, oestradiol, progesterone and immuno-reactive (ir-) inhibin during the oestrous cycle in goats Biotechnology Agronomy Society and Environment 584

Mori $\mathbf{Y}$ and Kano $\mathbf{Y}$ (1984) Changes in plasma concentrations of LH, progesterone and oestradiol in relation to the occurrence of luteolysis, oestrus and time of ovulation in shiba goats (Capra hircus) Journal of Reproduction and Fertility $\mathbf{7 2}$ 223-230

Nambo Y, Kaneko H, Nagat S, Oikawa M, Yoshihara T, Nagamine N, Watanabe G and Taya K (1998) Effect of passive immunization against inhibin on FSH secretion, folliculogenesis and ovulation rate during the follicular phase of the oestrous cycle in mares Theriogenology 50 545557

O'Shea T, Hillard MA, Anderson ST, Bindon BM, Findlay JK, Tsonis CG and Wilkins JF (1994) Inhibin immunization for increasing ovulation rate and superovulation Theriogenology 41 3-17

Pierson RA and Ginther OJ (1998) Ultrasonic imaging of the ovaries and uterus in cattle Theriogenology 29 21-37

Rajamahendran R, Robinson J, Desbottes S and Walton JS (1989) Temporal relationship among oestrus, body temperature, milk yield, progesterone and luteinizing hormone levels and ovulation in dairy cows Theriogenology 31 1173-1182

Riesenberg S, Meinecke-Tillmann S and Meinecke B (2001) Ultrasonic survey of follicular development following superovulation with a single application of pFSH, eCG or hMG in goats Small Ruminant Research 40 83-93

Rivier C and Vale W (1989) Immunization of endogenous inhibin modifies hormone secretion and ovulation rate in the rat Endocrinology 125152 157

Rosnina Y, Jainudeen MR and Nihayah M (1992) Superovulation and egg recovery in goats in the tropics Veterinary Record $13097-99$

Roy F, Maurel M, Combes B, Vaiman D, Cribiu E, Lantier I, Pobel T, Deletang F, Combarnous Y and Guillou F (1999) The negative effect of repeated equine chorionic gonadotropin treatment on subsequent fertility in Alpine goats is due to a humoral immune response involving the major histocompatibility complex Biology of Reproduction $\mathbf{6 0} 805$ 813

SAS (1987) Statistics, version 6.11, Cary, NC: SAS Institute Inc

Shi F, Mochida K, Suzuki O, Mateuda J, Ogura A, Ozawa M, Watanabe G, Suzuki A and Taya K (2000) Ovarian localization of immunoglobulin G and inhibin $\alpha$-subunit in guinea-pigs after passive immunization against the inhibin $\alpha$ subunit Journal of Reproduction and Development $\mathbf{4 6}$ 293-299

Sunderland SJ, Crowe MA, Boland MP, Roche JF and Ireland JJ (1994) Selection, dominance and atresia of follicles during the oestrous cycle of heifers Journal of Reproduction and Fertility 101 547-555

Takedomi T, Kaneko H, Aoyagi Y, Konishi K, Kishi H, Watanabe G and Taya K (1997) Effects of passive immunization against inhibin on ovulation rate and embryo recovery in Holstein heifers Theriogenology $471507-$ 1518

Taya K (1993) Role of inhibin in regulation of FSH secretion and folliculogenesis in mammals Current Trends in Experimental Endocrinology $\mathbf{1}$ $97-116$

Taya K and Watanabe G (1999) inhibin as a key hormone in determining species-specific ovulation rates in mammal. In Recent Progress in Molecular and Comparative Endocrinology pp 134-143 Eds HB Known, JMP Joss and S Ishii. Hormone Research Center, Chonman National University, Kwangju

Taya K, Watanabe G and Sasamoto S (1985) Radioimmunoassay for progesterone, testosterone and oestradiol $17 \alpha$ using ${ }^{125}$ I-iodohistamine radio ligands Japanese Journal of Animal Reproduction 31 186-197

Wang H, Herath CB, Xia G, Watanabe G and Taya K (2001) Superovulation, fertilization and in vitro embryo development in mice after administration of an inhibin-neutralizing antiserum Reproduction 122 809-816

Wheaton JE, Carlson KM and Kusina NT (1992) Active and passive immunoneutralization of inhibin increases follicle-stimulating hormone levels and ovulation rate in ewes Biology of Reproduction 47361 367

Wheaton JE, Thomas DL, Kusina T, Gottfrendson RG and Meyer RL (1996) Effects of passive immunization against inhibin-peptide on secretion of follicle-stimulating hormone and ovulation rate in ewes carrying the Booroola fecundity gene Biology of Reproduction 55 1351-1355

Wrathall JHM, McLeod BJ, Glencross RG, Beard AJ and Knight PG (1990) Inhibin immunoneutralization by antibodies raised against synthetic peptide sequences of inhibin $\alpha$ subunit: effects on gonadotrophin concentrations and ovulation rate in sheep Journal of Endocrinology 124 167-176

Received 24 September 2002.

First decision 3 January 2003.

Revised manuscript received 27 January 2003.

Accepted 30 January 2003. 